\title{
Dissolution profiles of partially purified bromelain from pineapple cores [Ananas comosus (L.) Merr] encapsulated in glutaraldehyde-crosslinked chitosan
}

\author{
Siswati Setiasih*, Hegi Adi Prabowo, Emil Budianto, Sumi Hudiyono \\ Department of Chemistry, Faculty of Mathematics and Natural Sciences, Universitas Indonesia, Depok, Indonesia.
}

\begin{tabular}{l}
\hline ARTICLE INFO \\
\hline Received on: $16 / 08 / 2018$ \\
Accepted on: 11/10/2018 \\
Available online: $31 / 10 / 2018$ \\
\\
\hline Key words: \\
Bromelain, purification, \\
post-loading encapsulation, \\
crosslinked chitosan, \\
dissolution.
\end{tabular}

\section{INTRODUCTION}

The per capita pineapple consumption of Indonesia increased by an average of $1.93 \%$ per year during 2002-2014, and 1.73 tons of pineapple was produced in 2015 (Respati, 2016). This increase in pineapple consumption was accompanied by the increased availability of pineapple waste products, including stems, skins, and cores. These wastes contain proteases that could be exploited in other applications (Ketnawa et al., 2012). The protease bromelain has a wide range of therapeutic effects, such as an antitumor agent, a platelet aggregation inhibitor, and an antibiotic absorption enhancer (Costa et al., 2014). Oral treatments with bromelain are complicated by contact with stomach fluids, which degrade the enzyme. In a previous study,

\footnotetext{
"Corresponding Author

Siswati Setiasih, Department of Chemistry, Faculty of Mathematics and Natural Sciences, Universitas Indonesia, Depok, Indonesia.

E-mail:setiasih@ui.ac.id
}

the proteolytic activities of bromelain were decreased in artificial stomach fluids but were relatively stable over the first 4 hours (Setiasih et al., 2018). Decreases in bromelain proteolytic activity followed deactivation and degradation by acidic stomach fluids and stomach enzymes. After encapsulation into controlled drug delivery devices, bromelain was absorbed into human intestines without losing activity (Chobotova et al., 2010). Hydrogels are widely used as raw materials for encapsulation and can swell owing to their hydrophilic and porous properties; therefore, these materials provide ease of design and control of crosslinking densities in matrixes (Gonçalves et al., 2005; Zhao et al., 2002). Chitosan-based hydrogels are widely used in many fields due to its excellent biodegradability, economic efficiency, and biocompatibility. These properties show that crosslinked-chitosan matrixes can be used as coating materials for controlled drug delivery systems. Furthermore, crosslinked-chitosan has a lot of primary amino groups $\left(-\mathrm{NH}_{2}\right)$ which can bind to biomolecules such as protein and DNA easily (Ou and Bo, 2017). In the present study, we crosslinked-chitosan by using glutaraldehyde 
and used the resulting preparation to coat bromelain from pineapple cores by using a post-loading method. Controlled drug delivery using this system was then evaluated in artificial stomach fluid $(\mathrm{pH}$ 1.2) and intestinal environments $(\mathrm{pH} 7.4)$ (Yadav and Shivakumar, 2012).

\section{MATERIALS AND METHODS}

\section{Materials}

Chitosan was purchased from CV. Bio Chitosan Indonesia. All other chemical reagents were purchased from Sigma-Aldrich.

\section{Isolation and ammonium sulfate fractionation of bromelain}

Pineapple cores were cut into pieces and crushed by using a blender under cold conditions. Core solutions were then filtered by muslin, and filtrates were centrifuged at $6,000 \mathrm{rpm}$ for 40 minutes at $\pm 4^{\circ} \mathrm{C}$. The resulting supernatants were designated crude enzyme fractions and were further fractionated for 20 minutes under cold conditions by using ammonium sulfate at concentrations of $0 \%-20 \%, 20 \%-50 \%$, and $50 \%-80 \%$ of the crude enzyme volume. Fractions were stored overnight ( \pm 12 hours) at $4^{\circ} \mathrm{C}$ and were then centrifuged at $6,000 \mathrm{rpm}$ for 15 minutes at $4{ }^{\circ} \mathrm{C}$. Precipitates were finally suspended in cold solutions of $0.2 \mathrm{M}$ phosphate buffer at pH 7 (Devakate et al., 2009).

\section{Dialysis}

Dialysis membranes containing enzymes were soaked in $100 \mathrm{ml}$ of $0.05 \mathrm{M}$ phosphate buffer at $\mathrm{pH} 7.0$ with continuous stirring at $4{ }^{\circ} \mathrm{C}$. Every 2 hours, phosphate buffer was replaced with fresh buffer phosphate, and precipitates were formed using $5 \%(\mathrm{w} / \mathrm{v}) \mathrm{BaCl}_{2}$ in acidic solution. The absence of $\mathrm{BaSO}_{4}$ precipitates indicated that dialysis was complete (Gautam et al., 2010).

\section{Purification by anion exchange chromatography}

Dialyzed enzymes were purified using anion exchange chromatography with a combination of stepwise and gradient elution. Enzyme solutions containing enzymes at up to $5 \%(\mathrm{v} / \mathrm{v})$ were added to columns containing DEAE-cellulose resin as the stationary phase. Columns were then eluted using $0.05 \mathrm{M}$ Tris- $\mathrm{HCl}$ buffer $(\mathrm{pH} 8)$ and then Tris- $\mathrm{HCl}$ containing $\mathrm{NaCl}$ at $0.25,0.50,0.70$, and $1.00 \mathrm{M}$ with a flow rate of $1.5 \mathrm{ml} /$ minute (Gautam et al., 2010). Eluents were collected in fraction vials ( $5 \mathrm{ml} /$ tube), and the absorbance of fractions was determined using UV-Vis spectrophotometry at $280 \mathrm{~nm}$. Data were graphed by plotting absorbance values against fraction numbers, and protein peaks were then calculated. The proteolytic activities of each fraction were finally analyzed and fractions were grouped to determine specific activity (Setiasih et al., 2018).

\section{Determinations of proteolytic activities and protein contents}

The proteolytic activities of the enzyme were determined according to the Kunitz method with some modifications by using a UV-Vis spectrophotometer at $280 \mathrm{~nm}$. The total protein contents of fractions were determined using the Lowry method according to the absorbance at $595 \mathrm{~nm}$ (Musfiroh et al., 2018).

\section{Synthesis of chitosan film and CGF}

Chitosan hydrogel was synthesized by adding $2 \mathrm{~g}$ of chitosan to $98 \mathrm{ml}$ of $1 \%(\mathrm{v} / \mathrm{v})$ acetic acid and then stirring at room temperature until the mixture became homogeneous. Noncovalent Chitosan Film (CF) was produced by molding the chitosan solution into a film and drying in an oven at $60^{\circ} \mathrm{C}$ overnight. CGF was synthesized by adding $0.1 \mathrm{M}$ glutaraldehyde at $10 \%(\mathrm{v} / \mathrm{v})$ to $2 \%$ chitosan solution and then stirring for 2 hours. The mixture was then molded into a film and was dried at $60^{\circ} \mathrm{C}$ for 12 hours. Hydrogels were stored in a desiccator before further use. CF and CGF were analyzed using Fourier transform infrared spectroscopy (FTIR) and optical microscopy (Budianto et al., 2015).

\section{Determination of degrees of crosslinking}

Dry CF and CGF films were weighed and soaked in 1\% acetic acid for 24 hours. CF and CGF were then removed and dried in an oven at $60^{\circ} \mathrm{C}$, and dry weights were recorded from before and after soaking. The degrees of crosslinking were calculated using the following equation (Abdel-Mohzen et al., 2011):

$$
\% \text { Degree of crosslinking }=\frac{W_{\mathrm{g}}}{W_{0}} \times 100 \%,
$$

where $W_{g}$ is the initial weight of the dry film and $W_{0}$ is the weight of the dry film after soaking in acetic acid.

\section{Determination of swelling ratios}

$\mathrm{CF}$ and CGF were weighed and soaked in phosphate buffer ( $\mathrm{pH} 7.0$ ) for 30 minutes at room temperature, and the remaining water on the surface of the hydrogel was removed. The wet weights of CF and CGF were then determined, and the swelling ratios were calculated using the following equation (Selvakumaran et al., 2016):

$$
\text { Swelling ratio }(\%)=\frac{W_{\text {wet }}-W_{\text {dry }}}{W_{\text {dry }}} \times 100 \% \text {. }
$$

\section{Encapsulation of bromelain using the post-loading method}

Bromelain enzyme dialysis fractions of $0.1 \mathrm{ml}$ were dropped into dry CFG, and the enzyme was then stored overnight to complete the encapsulation process. CFG surfaces containing bromelain were rinsed using $0.2 \mathrm{M}$ phosphate buffer ( $\mathrm{pH} 7)$. The amounts and activities of loaded bromelain were then calculated using the following equation (Croisfelt et al., 2015):

$$
\begin{aligned}
& \text { Loaded bromelain }=[\text { Bromelain }]_{\text {initial }}-[\text { Bromelain }]_{\text {dishwater }} \\
& \text { Loaded activity }=\left(\mathrm{U} \mathrm{ml}^{-1}\right)_{\text {initial }}-\left(\mathrm{U} \mathrm{ml}^{-1}\right)_{\text {dishwater }} .
\end{aligned}
$$
using FTIR

Finally, CGF-encapsulated bromelain was analyzed

\section{In vitro dissolution testing}

The dissolution profiles of bromelain in CGF were tested by placing $\mathrm{CGF}$ in $10 \mathrm{ml}$ aliquots of $\mathrm{HCl}$ buffer $(\mathrm{pH} 1.2)$ and then incubating at $37^{\circ} \mathrm{C}$ with shaking at $100 \mathrm{rpm}$. After 2 hours, the proteolytic activity and total protein contents in artificial stomach fluids were determined. CGF from $\mathrm{pH} 1.2$ buffer was finally 
incubated at $37^{\circ} \mathrm{C}$ in phosphate buffer $(\mathrm{pH} \mathrm{7.4)}$ for 10 hours with shaking at $100 \mathrm{rpm}$, and the proteolytic activity and total protein contents in the artificial intestinal environment were then determined (Reddy et al., 2018).

\section{RESULT AND DISCUSSION}

\section{Isolation of crude enzyme}

The Lowry method exploits the reduction of $\mathrm{Cu}(\mathrm{II})$ protein bonds underalkaline conditions. Released $\mathrm{Cu}^{2+}$ then oxidizes aromatic groups in amino acid side chains, thus resulting in the reduction of phosphomolybdotungstate to heteropolymolybdenum blue (Waterborg, 2002). The resulting color change is proportional to tyrosine and tryptophan contents and can be quantitated using UV-Vis absorbance. The determinations of proteolytic activity are optimal at $37^{\circ} \mathrm{C}(\mathrm{pH} 7)$ for 30 minutes. The proteolytic activity of bromelain is proportional to the production of trichloroacetic acidsoluble L-tyrosine from casein substrate. The specific activities of core solution and crude enzyme are shown in Table 1. The specific activity of the crude enzyme was higher than that of the pineapple core solution, which lacks pineapple fibers.

\section{Fractionation with ammonium sulfate and dialysis}

The fractionation of enzymes using ammonium sulfate is performed using the salting out principle, which is based on the stronger interactions between proteins than between proteins and solvents. High ammonium sulfate concentrations can dehydrate proteins in crude enzyme (dehydration process) preparations, thus causing aggregation and precipitation (Green and Hughes, 1955). Bromelain activities from fractionation and dialysis processes (Table 2) indicate increasing specific enzyme activities with processing steps. The highest specific activity was obtained from the second fraction, although high specific activity was also observed after the first fractionation step, and the enzyme solutions from this step were refractionated using $0 \%-50 \%$ ammonium sulfate. Subsequently, bromelain had increasing specific activities and purity. Dialysis was performed using principles of diffusion, and dialysis decreased the proteolytic activity with increasing volumes of the more dilute enzyme. However, nonbromelain proteins also diffuse through dialysis membranes, thus resulting in the increased specific activity and purity of the remaining bromelain.

\section{Purification using anion exchange chromatography}

Bromelain enzyme was purified using stepwise elution by an anion exchange chromatography column. In this process, proteins with relatively weaker binding are released and replaced by elution with low concentrations of $\mathrm{NaCl}$, and proteins with stronger binding affinity are released in subsequent elution stages. By using anion exchange chromatograms from $4.47 \mathrm{ml}$ elutes of bromelain dialysis (Fig. 1), four protein peaks were observed in plots of absorbance at $280 \mathrm{~nm}$. The proteolytic activities of each fraction were then tested and five protein peaks were obtained. After elution with $0.75 \mathrm{M} \mathrm{NaCl}$, a small protein peak was associated with the highest proteolytic activity. Fractions with the highest activity were then combined, and specific activities were determined (Table 3). The yield of combined fractions from anion exchange chromatography was small, thus reflecting the volume of enzyme added to the chromatography column. The highest specific activity of the enzyme was observed in the third protein peak $(\operatorname{Pr} 3)$, which corresponded to the mixture of fractions 58-71 (AP3). As shown in Table 3, AP3 had the highest purity of bromelain, which was eluted with $0.75 \mathrm{M} \mathrm{NaCl}$.

\section{$C F$ and $C G F$}

CGF was compared with CF to ensure that crosslinking reactions occurred. The compared parameters included morphology,

Table 1. Results of the bromelain isolation process.

\begin{tabular}{|c|c|c|c|c|c|c|}
\hline \multirow{2}{*}{ Fraction } & \multirow{2}{*}{ Volume (ml) } & \multicolumn{2}{|c|}{ Total } & \multirow{2}{*}{$\begin{array}{c}\text { Specific activity } \\
(\mathrm{U} / \mathbf{m g})\end{array}$} & \multirow{2}{*}{$\begin{array}{l}\text { Purification levels } \\
\text { (fold) }\end{array}$} & \multirow{2}{*}{ \%yield } \\
\hline & & Protein content (mg) & Proteolytic activity (U) & & & \\
\hline \multicolumn{7}{|c|}{ Homogenates were filtered, $T= \pm 4^{\circ} \mathrm{C}$} \\
\hline Core solution & 250 & 71.16 & 937.50 & 13.18 & - & - \\
\hline \multicolumn{7}{|c|}{ Centrifuge $6,000 \mathrm{rpm}, 45$ minutes, $\mathrm{T}= \pm 4^{\circ} \mathrm{C}$} \\
\hline Crude enzyme & 103 & 27.65 & 660.92 & 23.90 & 1 & 100 \\
\hline
\end{tabular}

Table 2. Bromelain activities after fractionation and dialysis.

\begin{tabular}{|c|c|c|c|c|c|c|}
\hline Fraction & Volume (ml) & \multicolumn{2}{|c|}{ Total } & $\begin{array}{l}\text { Specific activity } \\
\text { (U/mg) }\end{array}$ & $\begin{array}{l}\text { Purification levels } \\
\text { (fold) }\end{array}$ & \%yield \\
\hline F2 $(20 \%-50 \%)$ & 10 & 1.31 & 156.17 & 118.76 & 4.97 & 23.63 \\
\hline F3 $(50 \%-80 \%)$ & 2.2 & 0.27 & 9.53 & 35.27 & 1.48 & 1.44 \\
\hline \multicolumn{7}{|l|}{ Re-fractionation } \\
\hline F5 $(0 \%-50 \%)$ & 20 & 2.19 & 266.67 & 122.00 & 5.10 & 40.35 \\
\hline \multicolumn{7}{|l|}{ Dialysis } \\
\hline F5 dialysis & 22 & 2.04 & 256.30 & 125.48 & 5.25 & 38.78 \\
\hline
\end{tabular}




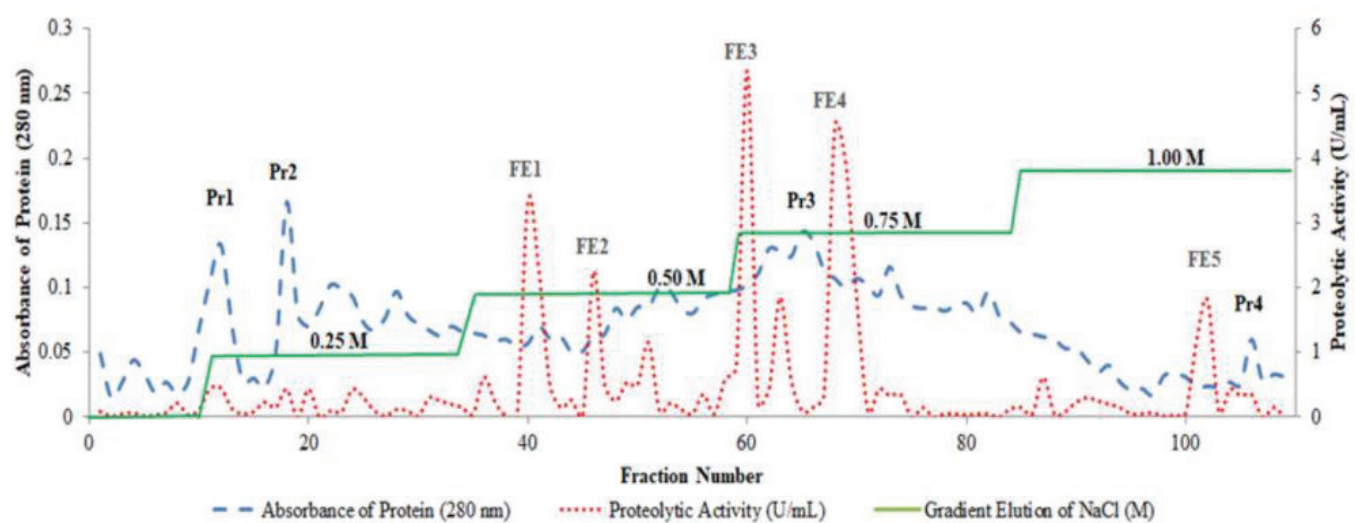

Figure 1. Chromatogram from F5 dialysis $(0 \%-50 \%)$ using a DEAE-cellulose matrix; Pr1-Pr4, the first to fourth protein peak at $280 \mathrm{~nm}$; FE1-FE5, the first to fifth proteolytic activity peak; separation conditions: column diameter, $2.8 \mathrm{~cm}$; column length, $50 \mathrm{~cm}$; matrix volume, $89 \mathrm{~cm}^{3}$; elution flow rate, $1.5 \mathrm{ml} /$ minutes; $5 \mathrm{ml}$ fractions were collected, and elution was performed using a linear gradient and stepwise elution. The column was initially eluted with $0.05 \mathrm{M}$ Tris-HCl buffer (pH 8.0) and then with the same buffer containing $0.25-1.0 \mathrm{M} \mathrm{NaCl}$.

Table 3. Combined fraction from anion exchange chromatography using DEAE-cellulose resin.

\begin{tabular}{|c|c|c|c|c|c|c|c|}
\hline \multirow[b]{2}{*}{ Fraction } & \multirow[b]{2}{*}{ Volume (ml) } & \multicolumn{2}{|c|}{ Total } & \multirow[b]{2}{*}{$\begin{array}{c}\text { Specific } \\
\text { activity }(\mathrm{U} / \mathrm{mg})\end{array}$} & \multirow[b]{2}{*}{$\begin{array}{l}\text { Purification levels } \\
\text { (fold) }\end{array}$} & \multirow[b]{2}{*}{ Yield (\%) } & \multirow[b]{2}{*}{ Recovery (\%) } \\
\hline & & $\begin{array}{c}\text { Protein } \\
\text { content }(\mathrm{mg})\end{array}$ & $\begin{array}{c}\text { Proteolytic activity } \\
\text { (U) }\end{array}$ & & & & \\
\hline AP1 (11-23) & 65 & 0.14 & 5.42 & 38.58 & 1.61 & 0.82 & 33.33 \\
\hline AP2 (40-52) & 65 & 0.04 & 3.25 & 86.21 & 3.61 & 0.49 & 9.52 \\
\hline AP3 (58-71) & 70 & 0.08 & 15.17 & 195.20 & 8.17 & 2.30 & 19.05 \\
\hline AP4 (100-106) & 35 & 0.02 & 0.58 & 28.74 & 1.20 & 0.09 & 4.76 \\
\hline
\end{tabular}

FTIR spectra, swelling ratios, and crosslinking degrees. The morphological observations of CF and CGF were made using an optical microscope (Fig. 3a and b, respectively) and showed that the films were dense, smooth, and uniform. However, CF had greater volumes and was less rigid than CGF, thus reflecting the crosslinking reactions of chitosan and glutaraldehyde under acidic conditions. These conditions resulted in nucleophilic reactions that produced neutral carbinolamine. Subsequent acid catalysis protonated the hydroxyl groups of tetrahedral carbinolamine and eliminated water molecules to form iminium ions. Furthermore, $\mathrm{H}^{+}$ions that were bound with nitrogen were released, and neutral imine products with $\mathrm{C}=\mathrm{N}$ bonds were formed. Such series of crosslinking reactions are known as Schiff base reactions (Banerjee et al., 2010). The FTIR spectra of bromelain showed $\mathrm{N}-\mathrm{H}$ stretch bands at $3,316 \mathrm{~cm}^{-1}, \mathrm{C}-\mathrm{H}$ stretches at $2,929 \mathrm{~cm}^{-1}$, strong intensities of $\mathrm{C}=\mathrm{O}$ stretch bands (amide 1 area) at 1,654 $\mathrm{cm}^{-1}$, and $\mathrm{C}-\mathrm{N}$ stretch bands at $1,540 \mathrm{~cm}^{-1}$ (Fig. $4 \mathrm{a}$ ) (Bernela et al., 2016). By contrast, chitosan spectra (Fig. 4b) showed a broadband at 3,500-3,080 $\mathrm{cm}^{-1}$, which resulted from the overlapping of $\mathrm{O}-\mathrm{H}$ and $\mathrm{N}-\mathrm{H}$ stretches. At a wave number of $1,659 \mathrm{~cm}^{-1}$, a $\mathrm{C}=\mathrm{O}$ stretch band indicated the presence of amides from residual acetyl groups in chitosan. Moreover, an $\mathrm{N}-\mathrm{H}$ bend stretch at $1,591 \mathrm{~cm}^{-1}$ indicated the presence of primary amine groups. The saccharide structure (glycoside bridge) of $\mathrm{C}-\mathrm{O}-\mathrm{C}$ bands appeared at 1,037 $\mathrm{cm}^{-1}$. The dominant differences between $\mathrm{CF}$ and CGF were seen in the absorption band at a wave number of $1595 \mathrm{~cm}^{-1}$, with a $\mathrm{C}=\mathrm{N}$ stretch for imine groups of CGF that formed because of the Schiff base reactions between the carbonyl groups of glutaraldehyde and amine groups from chitosan (Fig. 4c and d) (Budianto et al., 2015). The physical properties of CF and CGF were evaluated by determining the crosslinking degrees and swelling ratios. Hydrogels with high degrees of crosslinking were more rigid than hydrogels with low degrees of crosslinking. As shown in Table 4, the degrees of crosslinking for CGF were high compared with those of $\mathrm{CF}$, thus suggesting that small parts of chitosan are soluble in acetic acid and that CGF has higher degrees of crosslinking than $\mathrm{CF}$. The swelling ratios of hydrogels were investigated to determine the ability of hydrogels to absorb liquid (Table 4). The resulting data showed that the swelling ratios of CGF were lower than those of CF. In a previous study, hydrogel swelling was caused by repulsions between- $\mathrm{NH}_{3}^{+}$and amine groups in chitosan (Morris et al., 2009). Given that the amine groups in CGF were subjected to crosslinking reactions with glutaraldehyde, fewer protonated amine groups were observed in CGF. The visual appearances of crosslinking and the swelling ratio tests of CGF are presented in Figure 2.

\section{Encapsulation of bromelain in CGF}

A post-loading encapsulation method was chosen to enhance the efficiency of encapsulation and to use fewer enzymes. The encapsulation efficiencies shown in Table 5 corresponded to the differing appearances of CGF before and 


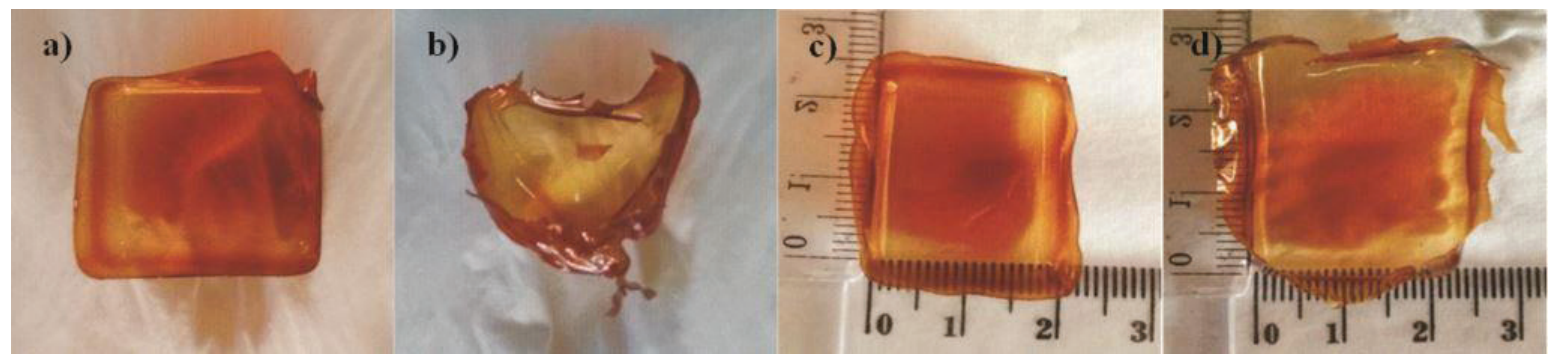

Figure 2. Visual appearances in tests of crosslinking degrees and swelling ratios of (a) CGF before testing the degrees of crosslinking, (b) CGF after testing the degrees of crosslinking, (c) CGF before the swelling ratio tests, and (d) CGF after the swelling ratio tests.

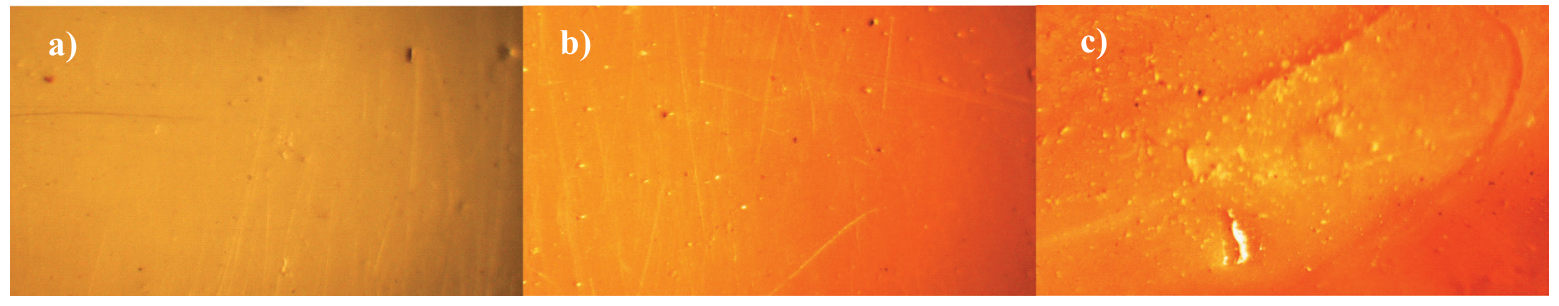

Figure 3. Morphological structure analyses using an optical microscope at $15 \times$ magnification; (a) morphological structure of chitosan film; (b) morphological structure of CGF before encapsulation; and (c) morphological structure of CGF after encapsulation.

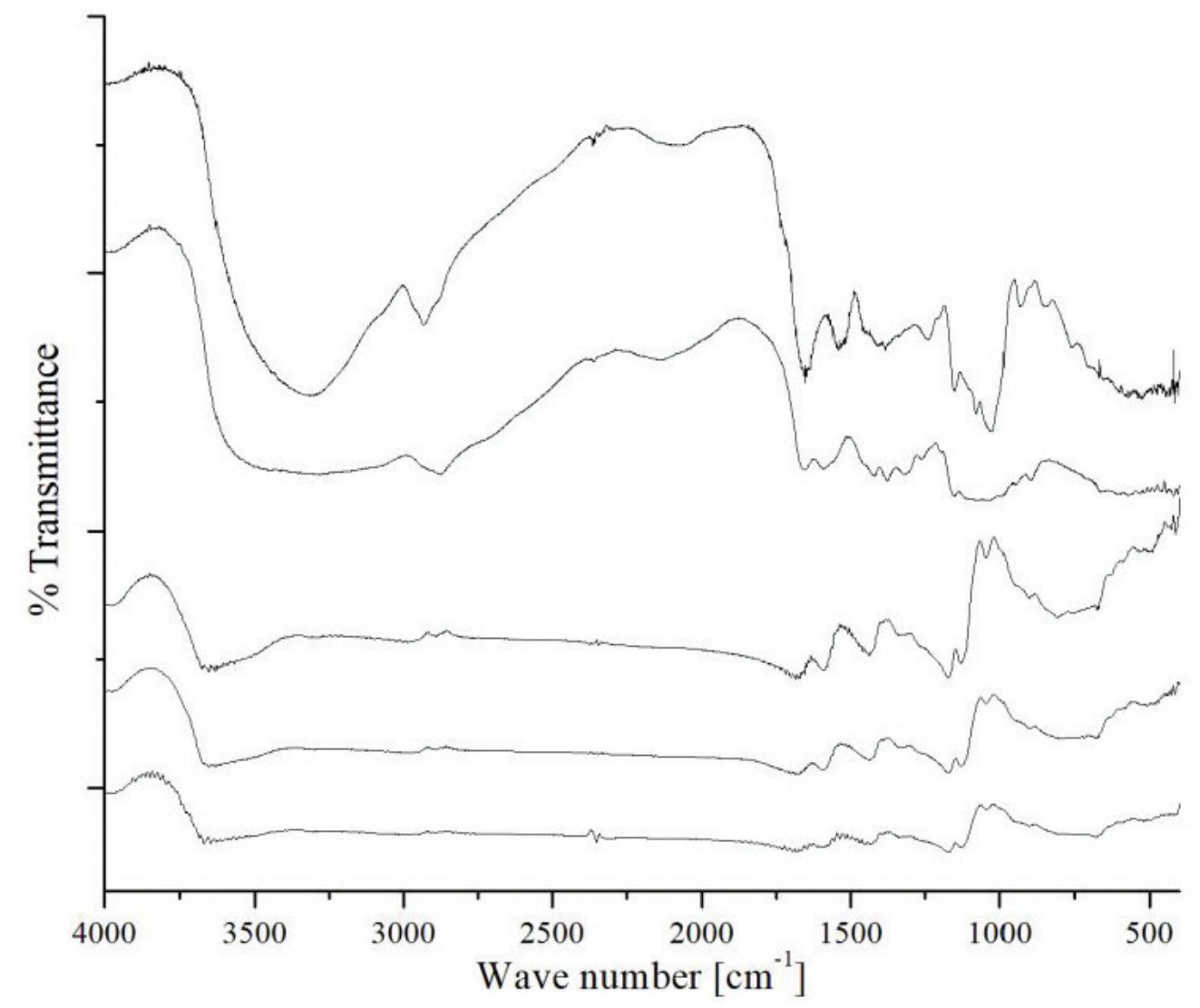

(a)

(b)

(c)

(d)

(e)

Figure 4. FTIR spectra of (a) bromelain, (b) powder chitosan, (c) CF, (d) CGF, and (e) bromelain encapsulated in CGF. 
Table 4. Degrees of crosslinking and swelling ratios of hydrogels $(n=3)$.

\begin{tabular}{lcc}
\hline Hydrogel & $\begin{array}{c}\text { Average of the degree of } \\
\text { crosslinking (\%) }\end{array}$ & $\begin{array}{c}\text { Average swelling ratio } \\
(\mathbf{\%})\end{array}$ \\
\hline CF & $0.48 \pm 0.02$ & $3078.84 \pm 105.31$ \\
CGF & $84.37 \pm 0.09$ & $76.60 \pm 1.15$ \\
\hline
\end{tabular}

after encapsulation (Fig. 3). In particular, the encapsulation of bromelain produced bubbles on hydrogels and led to smaller and rougher surfaces. In the subsequent FTIR analyses of hydrogels, a similar band was observed before and after encapsulation (Fig. 4d and e), thus indicating that no new bonds were formed following the addition of bromelain and that bromelain was absorbed well in CGF. The physical interactions between bromelain and CGF were due to hydrogen bond interactions, as indicated by changes in intensity at 3,500-3,080 $\mathrm{cm}^{-1}$ (Ataide et al., 2017). Furthermore, the absorption band shifted from 1,685 to $1,693 \mathrm{~cm}^{-1}$.
Table 5. Efficiency of bromelain encapsulation into CGF $(n=3)$.

\begin{tabular}{lccc}
\hline Material & $\begin{array}{c}\text { Protein levels loaded } \\
(\boldsymbol{\mu} \mathbf{g} / \mathbf{m l})\end{array}$ & $\begin{array}{c}\text { Proteolytic activity } \\
\text { loaded }(\mathbf{U} / \mathbf{m l})\end{array}$ & $\begin{array}{c}\text { Average of } \\
\text { encapsulation efficiency } \\
(\boldsymbol{\%})\end{array}$ \\
\hline CGF & $89.40 \pm 1.92$ & $8.32 \pm 0.14$ & $96.29 \pm 2.07$ \\
\hline
\end{tabular}

\section{In vitro dissolution tests}

Dissolution profiles were generated to determine the degree to which proteins or enzymes diffused out of the CGF matrix. Figure 5 shows that the proteolytic activity of bromelain in the artificial intestinal environment $(0.17 \pm 0.02 \mathrm{U} / \mathrm{ml})$ was greater than that in artificial stomach fluids $(0.03 \pm 0.02 \mathrm{U} / \mathrm{ml}$; Fig. 5). Moreover, the dissolution of bromelain in artificial stomach fluid $(37.41 \% \pm 5.70 \%)$ was higher than in the artificial intestinal environment $(10.07 \% \pm 3.73 \%)$, as shown in Figure 6 . These observations reflect the properties of CGF (Fig. 7a and b), which were more stable in the artificial intestinal environment than in artificial stomach fluid. Furthermore, in vitro dissolution

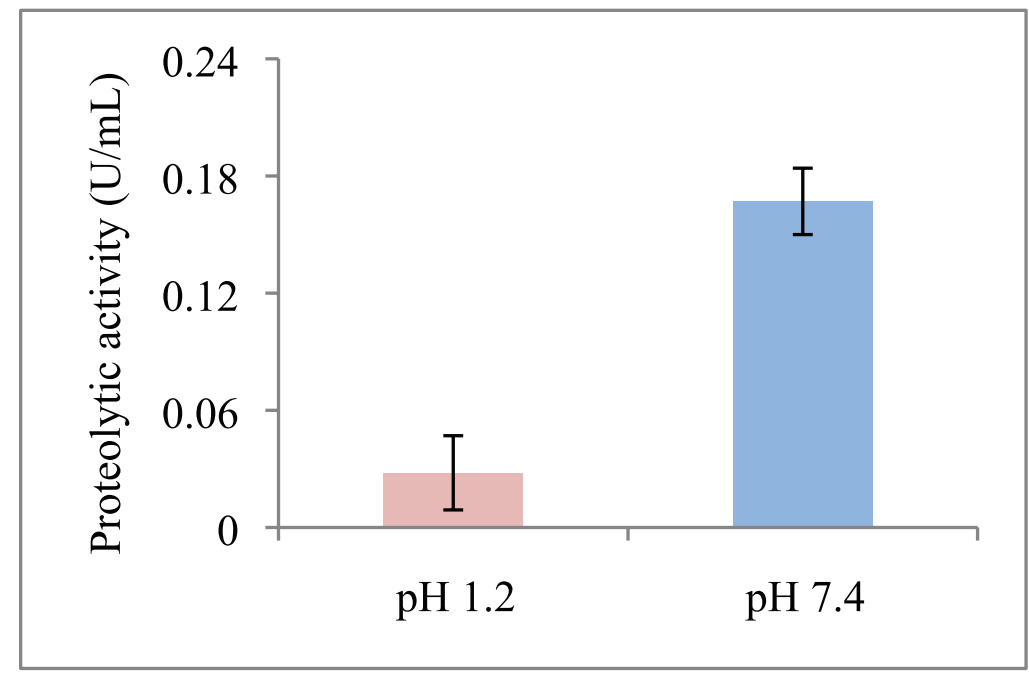

Figure 5. In vitro proteolytic profile of bromelain encapsulated in CGF $(n=3)$.

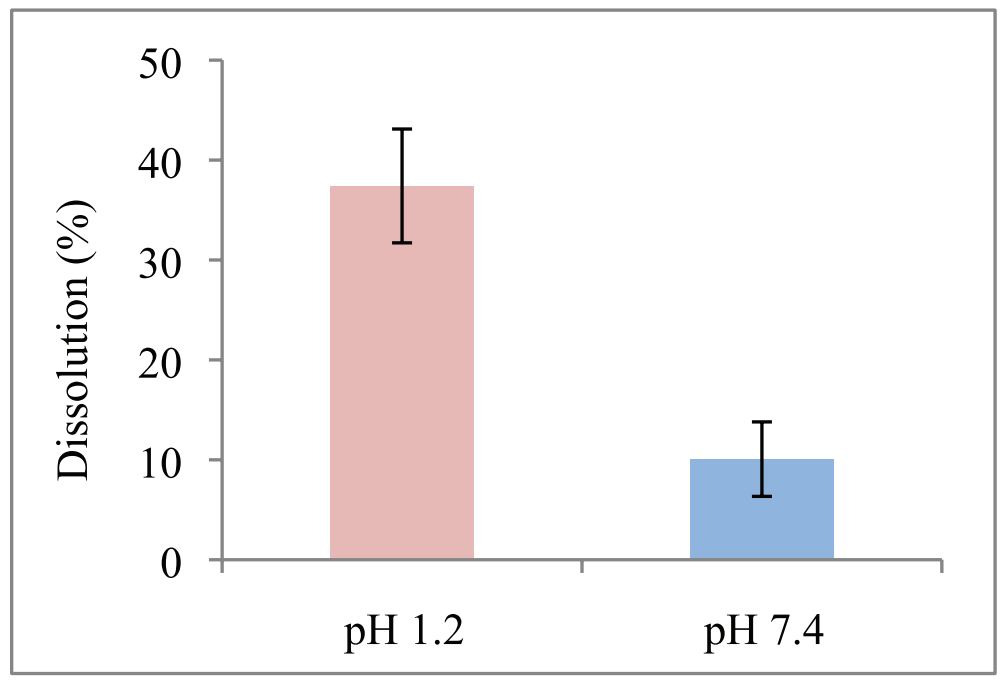

Figure 6. In vitro dissolution profile of bromelain encapsulated in CGF $(n=3)$. 
tests (Fig. 7c) caused the erosion of the hydrogel surface, and the resulting holes in CGF appeared during the first 2 hours immersion in acidic solutions $(\mathrm{pH} 1.2)$ and became larger when CGF was immersed in a $\mathrm{pH} 7.4$ solution for 10 hours. The constant influx of artificial stomach fluid and intestinal solutions through the matrix forced bromelain out of the CGF through the holes. The scanning electron microscopy (SEM) micrographs of the surfaces and cross-sections of amorphous CGF after encapsulation and dissolution tests (Fig. 8) show the cross sections of CGF and confirm that bromelain successfully entered CGF. Specifically, the image in Figure 8a shows bromelain in the middle of the CGF matrix, and the morphological micrograph in Figure $8 \mathrm{~b}$ indicates an even spread of bromelain on the CGF surface. Subsequent dissolution tests caused bromelain to diffuse and escape the CGF, as indicated by the heterogeneous white spot of bromelain and the dark background of CGF (Fig. 8c and d).

\section{CONCLUSION}

In this study, we isolated bromelain from pineapple cores and purified the enzyme by using ammonium sulfate fractionation and anion exchange chromatography with DEAE-cellulose resin. The highest specific activity (purest enzyme fraction) of bromelain was obtained from anion exchange chromatography. We also showed that CGF maintains bromelain activity until it is exposed to intestinal environments. Finally, the proteolytic activity of bromelain was greater in the artificial intestinal environment than in the artificial stomach fluid.

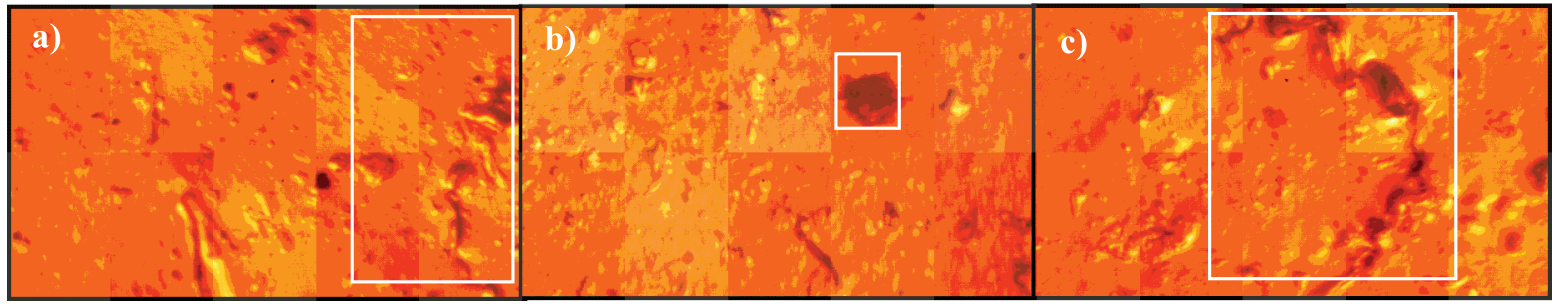

Figure 7. Morphological structure analyses of CGF matrix dissolution using an optical microscope at $45 \times$ magnification; (a) CGF in solution at $\mathrm{pH} 1.2$ for 2 hours, (b) CGF in solution at $\mathrm{pH} 7.4$ for 10 hours, and (c) CGF after in vitro tests; $\mathrm{pH} 1.2$ for 2 hours followed by $\mathrm{pH} 7.4$ for 10 hours.
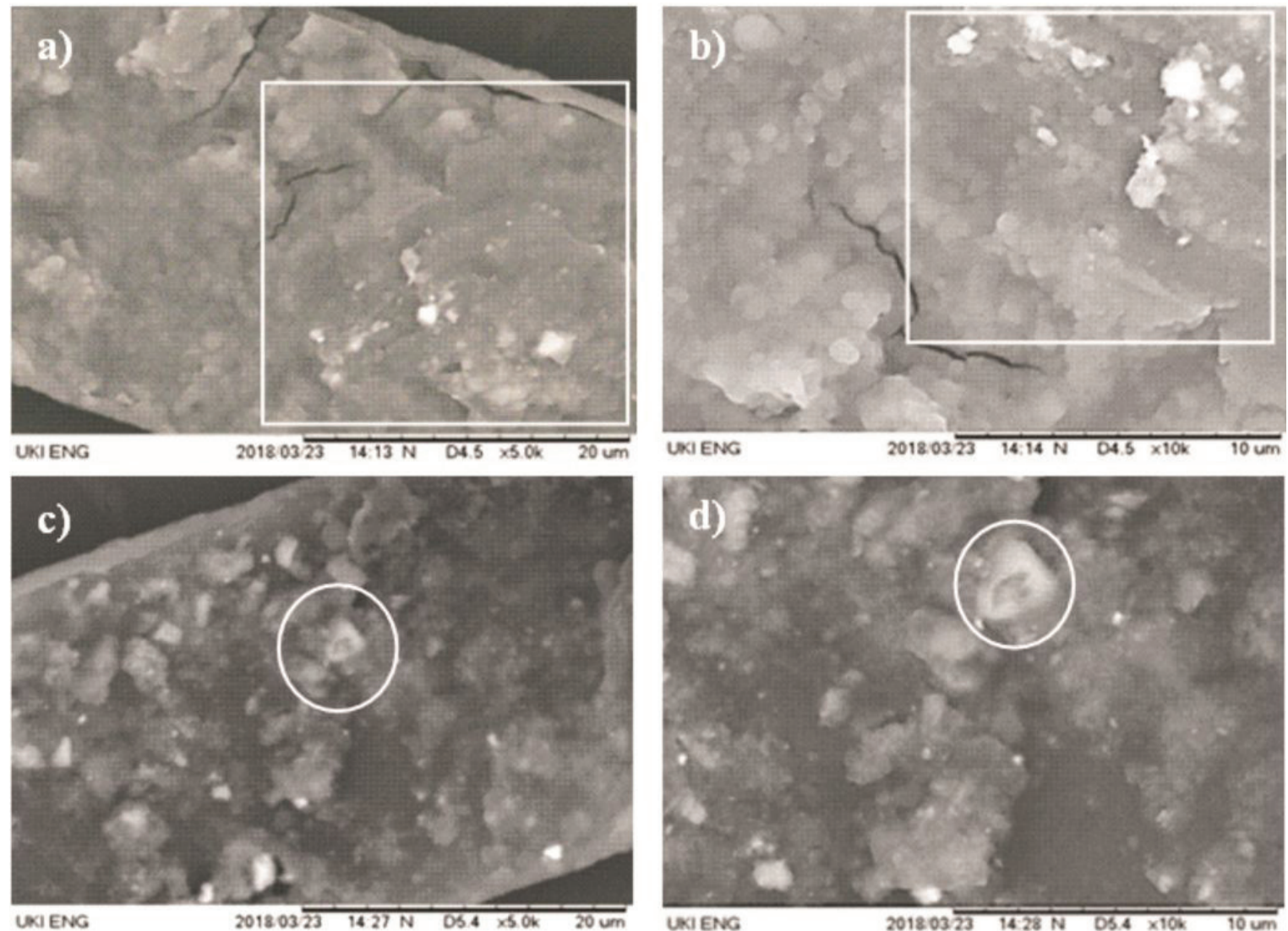

Figure 8. SEM micrographs of CGF matrixes after encapsulation; (a) cross section, 5,000× magnification; (b) surface, 10,000× magnification; CGF matrixes after dissolution test; (c) cross section at 5,000× magnification; (d) surface at 10,000× magnification. 


\section{FUNDING}

This research was financially supported by the Penelitian Dasar Unggulan Perguruan Tinggi (PDUPT) 2018 program of the Ministry of Research, Technology and Higher Education of the Republic of Indonesia.

\section{REFERENCES}

Ataide JA, Cefali LC, Rebelo MdA, Spir LV, Tambourgi EB, Jozala AF, et al. Bromelain loading and release from hydrogel formulated using alginate and arabic gum. Planta Med, 2017; 83:870-6.

Abdel-Mohzen AM, Aly AS, Hrdina R, Montaser AS, Hebeish A. Eco-synthesis of PVA/chitosan hydrogels for biomedical application. J Polym Environ, 2011; 19:1005-12.

Banerjee S, Siddiqui L, Bhattacharya S, Kaity S, Ghosh A, Chattopadhyay $\mathrm{P}$, et al. Interpenetrating polymer network (IPN) hydrogel microspheres for oral controlled release application. Int J Biol Macromol, 2010; 50:198-206.

Bernela M, Ahuja M, Thakur R. Enhancement of anti-inflamatory activity of bromelain by its encapsulation in katira gum nanoparticles. Carbohydr Polym, 2016; 143:18-24.

Budianto E, Muthoharoh SP, Nizardo NM. Effect of crosslinking agents, $\mathrm{pH}$ and temperature on swelling behavior of cross-linked chitosan hydrogel. Asian J App Sci, 2015; 3:581-8.

Chobotova K, Vernallis AB, Majid FAA. Bromelain's activity and potential as an anti-cancer agent: current evidence and perspectives. Cancer Lett, 2010; 290:148-56.

Costa HB, Fernandesa PMB, Romão W, Ventura JA. A new procedure based on column chromatography to purify bromelain by ion exchange plus gel filtration chromatographies. Ind Crops Prod, 2014; 59:163-8.

Croisfelt F, Martins BC, Rescolino R, Coelho DF, Zanchetta B, Mazzola PG, et al. Poly(N-Isopropylacrylamide)-co-acrylamide hydrogels for the controlled release of bromelain from agroindustrial residues of ananas comosus. Planta Med, 2015; 81:1719-26.

Devakate RV, Patil VV, Waje SS, Thorat BN. Purification and drying of bromelain. Sep Purif Technol, 2009; 64:259-64.

Gautam SS, Mishra SK, Dash V, Goyal AK, Rath G. Comparative study of extraction, purification and estimation of bromelain from stem and fruit of pineapple plant. Thai J Pharma Sci, 2010; 34:67-76.

Gonçalves VL, Laranjeira MCM, Fávere VT. Effect of crosslinking agents on chitosan microspheres in controlled release of diclofenac sodium. Polímeros Ciência Tecnologia, 2005; 15:6-12.

Green AA, Hugesh WL. Protein solubility on the basis of solubility in aqueous solutions of salt and organic solvents. Methods Enzymol, 1955; 1:67-90.
Ketnawa S, Chaiwut P, Rawdkuen S. Pineapple wastes: a potential source for bromelain extraction. Food Bioprod Proc, 2012; 90:385-91.

Morris G, Castile J, Smith A, Adams GG, Harding SE, Macromolecular conformation of chitosan in dilute solution: a new global hydrodynamic approach. Carbohydr Polym, 2009; 76:616-21.

Musfiroh FF, Setiasih S, Handayani S, Hudiyono S, Ilyas NM. In vivo antiplatelet activity aggregation assay of bromelain fractionate by ethanol from extract pineapple core (Ananas comosus [L.] Merr). IOP Conf Ser Mat Sci Eng, 2018; 299:1-4.

Ou A, Bo I. Chitosan hydrogels and their glutaraldehydecrosslinked counterparts as potential drug release and tissue engineering system-synthesis, characterization, swelling kinetics and mechanism. J Phys Chem Biophys, 2017; 3:1-7.

Reddy GV, Reddy NS, Nagaraja K, Rao KSVK. Synthesis of $\mathrm{pH}$ responsive hydrogel matrices from guar gum and poly (acrylamideco-acrylamidoglycolicacid) for anti-cancer drug delivery. J App Pharm Sci, 2018; 8:84-91.

Respati E. Outlook nenas. Pusat Data dan Sistem Informasi Pertanian Sekretariat Jenderal Kementerian Pertanian, Jakarta, Indonesia, 2016.

Selvakumaran S, Muhamad II, Razak SI. Evaluation of kappa carrageenan as potential carrier for floating drug delivery system: effect of pore forming agents. Carbohydr Polym, 2016; 135:207-14.

Setiasih S, Darwis AAC, Dzikria V, Hudiyono S. Stability test of partially purified bromelain from pineapple (Ananas comosus (L.) Merr) core extract in artificial stomatch fluid. IOP Conf Ser Mater Sci Eng, 2018; 299:1-7.

Waterborg JH. The lowry method for protein quantitation. In: Walker JM (ed.). The protein protocols handbook second edition. Humana Press, New Jersey, pp 7-9, 2002.

Yadav HKS, Shivakumar HG. In vitro and in vivo evaluation of $\mathrm{pH}$-sensitive hydrogel of carboxymethyl chitosan for intestinal delivery of theophylline. ISRN Pharm, 2012; 2012(article ID 763127):1-9.

Zhao HR, Wang K, Zhao Y, Pan LQ. Novel sustained-release implant of herb extract using chitosan. Biomaterials, 2002; 23:4459-62.

\section{How to cite this article:}

Setiasih S, Prabowo HA, Budianto E, Hudiyono S. Dissolution profiles of partially purified bromelain from pineapple cores [Ananas comosus (L.) Merr] encapsulated in glutaraldehydecrosslinked chitosan. J App Pharm Sci, 2018; 8(10): 017-024. 